\title{
THE IMPACT OF INFRASTRUCTURE SPENDING ON ECONOMIC GROWTH: A CASE STUDY OF INDONESIA
}

Makmun Syadullah, Dhani Setyawan*

Fiscal Policy Agency, Ministry of Finance of the Republic of Indonesia, Jakarta, Indonesia

*E-mail of corresponding author: dhanisetyawan83@gmail.com

\section{Resume}

This paper aims to analyze the impact of infrastructure spending on economic growth in Indonesia, which includes investment in road, port and irrigation infrastructure. The period of observation was 2011-2018, which covered 29 provinces with consideration of data availability. This study employed the growth model with a panel data analysis, which analyze the relationship between the economic growth and government investment in infrastructure in the long run. The most essential finding in this study is that the economic growth is positively influenced by government investment in road, port and irrigation infrastructure. Road infrastructure investment has a significant positive impact and the effect occurs in the fourth year after infrastructure development. In comparison, port and irrigation infrastructure investment have a positive but not significant impact to other variables.

\section{Article info}

Received 20 November 2020

Accepted 23 December 2020

Online 19 May 2021

\section{Keywords:}

infrastructure investment, economic growth, transportation, public investment, agriculture

ISSN 1335-4205 (print version) ISSN 2585-7878 (online version)

\section{Background}

Current development, including infrastructure development, will determine the future civilization. Infrastructure development will create more robust connectivity more evenly throughout the country. The availability of adequate infrastructure will minimize disparities between regions, reduce logistics costs and reduce the economic inequality between regions in Indonesia. Furthermore, infrastructure development will also improve community welfare.

The impact of infrastructure development on economy cannot be enjoyed directly. It takes at least a short amount of time to feel the effect. The study of measuring the performance of public infrastructure development on new economic growth was carried out around the 1990s [1]. Further, the study of relationship between the infrastructure development and economic growth was carried out in the period 1990-1995 [2]. In the next era, research on the impact of forest development on poverty became the focus of research. Various research findings show that results are very varied, even seem contradictory. According to [3], infrastructure measurement from the expenditure side is considered as the leading cause of conflicting research results compared to the size in terms of performance, which is due to various reasons. First, ignoring the contribution of infrastructure spending by the private sector and secondly, there are inconsistencies in infrastructure funding.
According to [4], there is a positive relationship between the economic growth and infrastructure spending. The availability of more significant infrastructure is a driver of economic growth. Investment in infrastructure will also encourage increased productivity and create externalities. Further, it also reduces transportation costs and production costs

China is one of countries that succeed in building infrastructure. The Chinese government spending on infrastructure is enormous in the hope that it will drive the economic growth. Many other countries are fascinated by China's infrastructure development policies. But the fact is, according to [5] that the infrastructure development in China is not much different from those of other countries. Chinese investment is generally in unproductive projects, which fail. The benefits expected at the beginning of growth were not realized; even the project was a burden to the economy, due to excessive investment in unproductive projects funded with debt. Further, results in debt buildup, economic fragility, unstable financial markets and expansion in the monetary sector. What happened in China must be a lesson for other countries.

In the era of President Joko Widodo, infrastructure development in Indonesia was a top priority, which can be proven from the portion of the financing in 2018, reaching around $18.6 \%$ of total government expenditure. According to the performance report of the Ministry of Public Works and Public Housing, the output of road length increased, exceeding the target up to 3 times. 
Will infrastructure development carried out massively in various regions in Indonesia have a positive impact on economic growth? This paper has analyzed the effect of infrastructure spending, specifically road, port and irrigation infrastructure on economic growth in Indonesia. The investment period analyzed is 20112018, which covers 29 provinces taking into account the availability of data.

\section{Literature review}

\subsection{Definition of infrastructure}

According to [6], infrastructure is defined as, "those services derived from the set of public work traditionally supported by the public sector to enhance private-sector production and to allow for household consumption". Meanwhile, according to [7] infrastructure is a physical system that provides transportation, irrigation, drainage, buildings and other public facilities, which are needed to meet basic human needs both social and economic conditions. Further [7] also defines infrastructure as a physical system that provides transportation, irrigation, drainage, buildings and facilities other public. This infrastructure is needed to meet basic human needs, both economic and social. In contrast, [8] defines infrastructure as a system that supports social and economic networks. Infrastructure is also a connector for the environmental system, where this system can be used as a basis for making policies.

Both central and regional governments provide infrastructure like public services to support and encourage the economic and social activities of the community. The provision of infrastructure is tailored to each region's needs so that it can improve the welfare of the city. Urban society requires different infrastructure from rural communities, as well as between regions industry with agriculture and coastal areas.

Infrastructure is non-exclusive (no one can be excluded), non-rival (consumption of an individual does not reduce the consumption of other individuals). Besides that, in general, marginal production costs are zero and cannot be traded (non-tradable).

Some types of infrastructure (such as toll roads) do not include pure public goods, even though the government provides them. The use of available goods is the non-rivalry and non-excludable rivalry. Rivalry in the sense that if someone uses an item, the item cannot be used by someone else. However, if on the contrary the goods were used by other people or used jointly, then the goods are public goods. The use of infrastructure is not directly charged, because the government provides the infrastructure as a support for social-economic activities.

Infrastructure, such as roads, education, health are the positive externalities. Providing support to these facilities can increase the productivity of all the inputs in the production process [9]. Positive externalities in infrastructure, in the form of increased production of companies and the agricultural sector, without having to raise input capital and labour, also increase the level of technology.

\subsection{Infrastructure and growth}

As a reference in analyzing economic growth models, the Solow growth model is often used. The model assumes that economic growth is influenced by three factors, namely savings, investment and population growth. Meanwhile, technological changes that describe the level of efficiency are assumed to be exogenous and are considered residuals. According to [10], the Solow Model is a growth model developed by Harrod-Domar, by adding labour and technology factors to the growth equation.

Infrastructure in the aggregate production function is considered as additional input [11]. The effect of public spending on development of the endogenous growth model was considered in [12]. Subsequent research was conducted by authors of [13] adding the private capital stock. Furthermore, the impact of infrastructure development on economic growth was examined in [14], as well. The results show a positive effect, a decrease in the number of poor people and an increase in the environment.

One important indicator that is often used to measure economic conditions in a country in a certain period is the Gross Domestic Product (GDP). Transportation facilities are needed to reduce the gap between consumers and producers. Thus, the means of transportation play a critical role as a means of connecting parties who need each other. Transport infrastructure plays a role in overcoming obstacles that disrupt the smooth flow of goods and people through the land, sea and air modes.

Some of the main variables that influence economic growth are the capital accumulation (including investment in land, physical equipment), human resources and technological progress. The capital accumulation would occur if a portion of the income received is reinvested to increase revenue in the future. This productive investment must be supported by investment in social and economic infrastructure, which includes the construction of roads, electricity supply, availability of clean water, irrigation channels, improvement of sanitation, construction of communication facilities and so on.

As a driver of economic growth, economic infrastructure plays a significant role. The intended economic infrastructure is public goods. As public goods, according to the theory of infrastructure, it has the character of an externality, because the government provides it and for each party that uses infrastructure does not pay directly.

Infrastructure development will have an economic 
and social impact. The availability of adequate infrastructure can support economic activities and will affect the economic growth. According to [9], infrastructure has positive externalities because it can increase productivity in the production process. Positive externalities can take the form of increased production of companies and the agricultural sector without having to raise capital and labour input or also increase the level of technology.

Infrastructure is a link between various centres of economic activity and the surrounding area. In remote areas where the population is usually isolated, they live in poverty. Farmers have difficulty marketing their agricultural products, so they are burdened with high costs. As a result, the added value of agricultural products is low. Conditions like this are a barrier for poor people, on the one hand, infrastructure development will increase access for the community, on the other hand, it will make it easier for the government to overcome poverty. Improved access to infrastructure will reduce the costs of living and open opportunities for the poor to benefit from economic growth.

\subsection{Previous research}

One key to achieving higher and stable economic growth is availability of infrastructure. According to [15], many countries in Asia develop the necessary infrastructure, but rather focus on quantity rather than quality. To reduce the distance between regions and the link between national markets at low costs requires quality infrastructure [16].

Many research has been done on how the infrastructure investment affects economic growth. Authors of [11-12] use indicators of public capital to measure infrastructure as additional input in the production function of further research, while in [17] and [18] they use indicators of transportation, electricity and communication to measure infrastructure.

Transportation infrastructure is needed to achieve higher economic growth. This critical role of transportation infrastructure is used as a reason by many countries to build road infrastructure in disadvantaged areas to stimulate economic growth. Results of research supporting this reason are shown in [19] and [20] that the public infrastructure has an impact on increasing productivity and economic growth. Research on the effects of transportation infrastructure using indicators of road density in 48 U.S. states during the period 1960-1985 was conducted in [21]. The results show that the quantity and quality of highways have a positive impact on economic growth. Research with similar products was carried out in [22], which shows that economic growth is affected by the length of roads per thousand inhabitants, exports per capita, education expenditure per capita and physical capital stock per worker. The relationship between the economic growth and U-shaped urbanization is reversed. Economic growth will increase at a low rate of urbanization. However, when urbanization exceeds the threshold level, economic growth would decline.

Meanwhile, the port infrastructure also has a positive impact on economic growth. Authors of [23] show a positive relationship between the value-added in Chinese ports and regional economic development. This study contradicts the results of a previous study conducted in [24], which showed that ports have a declining effect on the economy.

Authors of [25] also researched the impact of port development on economic growth. Their research results led to conclusion that several companies in Hampton, United States, suffered losses due to port shortages. Meanwhile, according to results of [26], each million tons of net port throughput will create around 400-600 jobs in the Western European region. Meanwhile, according to [27], whenever there is a $10 \%$ increase in throughput at ports, the revenue will increase $6-20 \%$ of the regional GDP. At the same time, the surrounding areas will also enjoy an increase in income of approximately $5-18 \%$.

Meanwhile, the development and management of irrigation infrastructure are closely related to national food security and economic politics in a country. Community access to irrigation infrastructure will have an impact on economic growth. With access to irrigation, the level of income and expenditure of the community will also increase. Thus, the irrigation infrastructure not only impacts income, output and welfare but can also contribute to poverty reduction, through the effects of income and consumption smoothing.

Research on the impact of irrigation infrastructure development on poverty alleviation was conducted in [28]. The results show that areas without irrigation infrastructure have high levels of poverty both in terms of income and consumption, while the lowest are in areas with adequate access to irrigation infrastructure.

\subsection{Research methodology}

The main problem faced with in the study of the impact of infrastructure investment on economic growth is the measurement of infrastructure investment. Various indicators to measure infrastructure investment have been used in several previous studies. Indicators of public capital are used iny [29-31]. Authors of [19] employed transportation, water and communication indicators. Road, telephone and electricity indicators are used byCanning in [20]. Meanwhile, physical capital stock indicators are used in [32-34]. 
Table 1 Percentage of infrastructure budget allocation based on islands and Economic Growth 2010-2017 (Source: Ministry of Finance of the Republic of Indonesia)

\begin{tabular}{|c|c|c|c|c|}
\hline & road & port & irrigation & growth rate \\
\hline Sumatera & 20.80 & 12.09 & 23.40 & 2.83 \\
\hline Java & 21.41 & 11.21 & 23.02 & 5.62 \\
\hline Kalimantan & 4.30 & 7.23 & 6.07 & 2.76 \\
\hline Sulawesi & 14.30 & 11.48 & 10.89 & 2.88 \\
\hline others & 28.63 & 58.00 & 36.47 & 5.62 \\
\hline
\end{tabular}

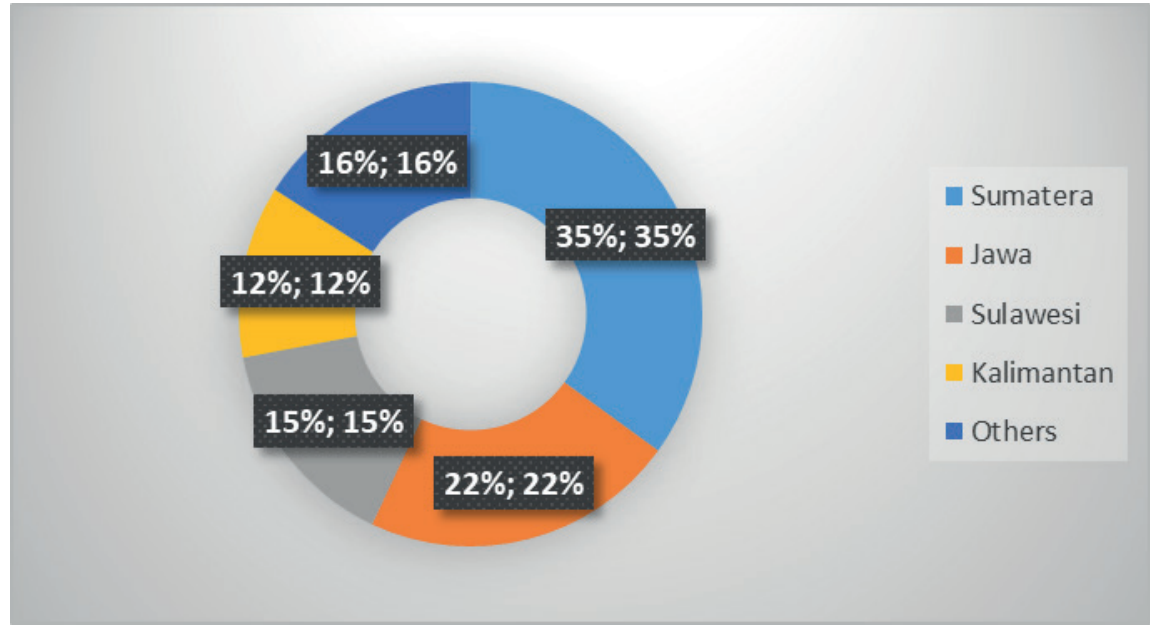

Figure 1 Distribution of Road Length by Island in 2017

(Source: Central Bureau of Statistics of the Republic of Indonesia)

In this paper, the infrastructure investment is proxied from central government investment in the province, which includes investment in roads, ports and irrigation. Given the unavailability of infrastructure investment data by local governments, both cities, districts and provinces, the acquisition is not taken into account. As data limitations, only 29 regions were selected out of 34 areas in Indonesia.

The problem that has the potential to interfere with the research results in this study is the geographical problem. Indonesia, with 34 provinces and 17,504 islands has different characteristics so that the economic growth rate of one region is different from the other areas. As a result, the central government investment in infrastructure in each region is also additional. This study ignores geographical problems.

The growth model used in this paper is a panel data analysis model developed by Canning and Pedroni in [9]. This model is used to analyze whether there is a relationship between economic growth and government investment in infrastructure in the long run. Government investment data per province for the period 2011-2017 and economic growth data were obtained from the Ministry of Finance and Statistics Agency. The model used here is:

$\mathrm{EG}=\beta 0+\beta 1 \log (\mathrm{road})+\beta 2 \log ($ port $)+$ $+\beta 3 \log ($ irrigation), where: E.G.: economic growth, road: public investment in the road sector, port: public investment in the port sector, irrigation: public investment in the irrigation sector.

In this paper, the time element is included, to find out in what year infrastructure investment began to have an impact on economic growth. This study employs three tests to choose the best panel data regression model, namely: General Effects, Permanent Effects or Random Effects). The F Test (Chow Test), Hausman Test and Lagrange Multiplier Test (L.M.) were conducted, as well.

\section{Data analysis and discussion}

\subsection{Development of infrastructure investment}

One of the triggers for economic growth is infrastructure development. For this reason, in the context of building infrastructure, mostly road, port and irrigation infrastructure, government investment continues to increase from year to year. The road infrastructure investment increased from USD 1.06 billion in 2010 to USD 2.4 billion in 2017 or an average increase of $15.61 \%$ per year. The port infrastructure investment increased from USD 78.4 million in 2010 to USD 422.3 million in 2017 or an average increase of $55.03 \%$ per year. In comparison, irrigation 
Table 2 Development of Unloading and Loading at Ports for the 2010-2017 Period (million tons) (Source: Central Bureau of Statistics of the Republic of Indonesia)

\begin{tabular}{lcccc}
\hline & \multicolumn{2}{c}{ domestic port } & \multicolumn{2}{c}{ international port } \\
\cline { 2 - 5 } & uploaded & loaded & uploaded & loaded \\
\hline 2010 & 221.68 & 182.48 & 65.64 & 233.22 \\
2011 & 284.29 & 238.94 & 78.84 & 376.65 \\
2012 & 327.72 & 312.60 & 69.51 & 488.26 \\
2013 & 336.06 & 303.88 & 89.51 & 510.70 \\
2014 & 381.60 & 328.74 & 100.57 & 417.16 \\
2015 & 318.68 & 296.17 & 98.52 & 342.66 \\
2016 & 361.58 & 324.11 & 92.94 & 313.18 \\
2017 & 409.34 & 334.11 & 105.49 & 272.40 \\
\hline
\end{tabular}

infrastructure investment increased from $\mathrm{Rp} 208.7$ million in 2010 to $\mathrm{Rp} 1.7$ billion in 2017 or an average increase of $91.78 \%$ per year.

The road infrastructure receives the largest investment allocation. In the observed period (20102017) the total portion of investment allocation for roads reached $65.99 \%$, irrigation $22.10 \%$ and the smallest for ports was $11.91 \%$. While taking into account regional infrastructure needs, the total budget allocation for roads, ports and irrigation for Papua, Ambon, West Nusa Tenggara and East Nusa Tenggara in the period 2010-2017 reached $33.86 \%$, Java $20.55 \%$, Sumatra 20, 37\%, Sulawesi $13.58 \%$ and Kalimantan $11.64 \%$. At the same time, the allocation based on the island and the type of infrastructure can be seen in Table 1.

When measured in terms of island size, investment allocations for the road, port and irrigation infrastructure do not yet reflect a sense of justice. The Java Island received the most considerable portion, reaching $20.55 \%$. In contrast, the area of Java was only $128,297 \mathrm{~km}^{2}$ or $6.73 \%$ of the land area of Indonesia, Papua, Ambon, West Nusa Tenggara and East Nusa Tenggara received allocations of $33.86 \%$. In contrast, the total area reaches $385,292 \mathrm{~km}^{2}$ or $20.23 \%$ of the land area of Indonesia. Sulawesi with an area of $174,600 \mathrm{~km}^{2}$ or $9.17 \%$ of the land area of Indonesia received an allocation of $13.58 \%$. Kalimantan with an area of $743,330 \mathrm{~km}^{2}$ or $39.02 \%$ of the land area of Indonesia received a share of $11.64 \%$.

Meanwhile, Sumatra with an area of 473,481 $\mathrm{km}^{2}$ or $24.85 \%$ of the land area of Indonesia received an allocation of $20.37 \%$. However, if the factor of the population is one of the considerations, the investment allocation for infrastructure already reflects justice. Based on the projections of the Central Statistics Agency, in 2020 the number of residents living in Sumatra reached $21.89 \%$, Java $56.24 \%$, Kalimantan $6.19 \%$, Sulawesi $7.35 \%$ and other regions $8.33 \%$. Investment allocation also considers natural conditions.

Along with the increasing number of cars and motorcycles, the allocation of investment for the road infrastructure has also increased. In the 20102017 period the number of vehicles and motorcycles nationwide nearly doubled, from 76.91 million units to 137.21 million units. The increase in transportation modes is driving an increase in the allocation of investment for roads. This investment is used to add new routes and repair damaged roads. National road length (not including tolls) in 2017 reached 539.41 thousand $\mathrm{km}^{2}$, with distribution in Sumatra $35 \%$, in Java $22 \%$, Sulawesi $15 \%$, Kalimantan $12 \%$ and other islands $16 \%$ (see Figure 1). Based on the distribution of the length of the road, the allocation of road infrastructure investment has reflected the needs.

An increase in the port activity leads the government to increase investment in port infrastructure, or conversely, an increase in investment is that in the period 2010-2017, activities at ports, both uploaded and loaded at domestic and foreign ports, experienced relatively high growth (see Table 2). For domestic ports, uploading activity increased from 221.67 million tons to 409.34 million tons and packing activity has risen from 182.48 million tons to 334.11 million tons. As for international shipping, uploaded activity increased from 65.64 million tons to 105.49 million tons and loading activity rose from 233.22 million tons to 272.40 million tons.

Based on the area of the rice harvest, the allocation of infrastructure investment in irrigation does not seem to reflect the needs. Based on data from the Central Bureau of Statistics, the largest rice crop harvest area is in Java, which reaches $50.27 \%$ but receives only an allocation of irrigation infrastructure investment of $23.02 \%$. In comparison, other regions that have only $6.34 \%$ paddy crop area received an irrigation infrastructure investment allocation of $36.47 \%$. The distribution of irrigation infrastructure investment allocations might consider other factors, such as ease of access to water. The availability of water in Java, in general, is more abundant compared to other islands so that the infrastructure development does not require high costs. The ease of accessing water is also reflected in the rice productivity. In 
Table 3 Data Panel Results

\begin{tabular}{cccc}
\hline \multirow{2}{*}{ variable } & \multicolumn{3}{c}{ coefficient } \\
\cline { 2 - 4 } C & $\mathrm{t}-1$ & $\mathrm{t}-2$ & $\mathrm{t}-4$ \\
road & 183257.8 & 255307.7 & $2035645^{*}$. \\
port & $-0.790838^{* *}$ & $-1.762631^{*}$ & 0.085962 \\
irrigation & 0.144117 & $0.462570^{* *}$ & 0.013157 \\
R-squared & -0.414692 & $-0.357435^{* *}$ & 0.672672 \\
adjusted R-squared & 0.522462 & 0.411494 & 0.613332 \\
\hline
\end{tabular}

Note: ${ }^{*}$ significant at the $5 \%$ level and $* *$ significant at the $10 \%$ level

Java, the rice productivity per hectare reaches 5.69 tons, which is above the national average of 5.20 tons. In contrast, productivity on other islands is below the national average.

\subsection{Data analysis and discussion}

Based on the results of data processing, using the economic growth panel model, Table 3 shows that the random effects for $t-4$ are better to be used than the fixed effects (F.E.) and General Effects (C.E.), both at t- 1 and $\mathrm{t}-2$ levels.

Government investment in the road and irrigation sector in the first and second year has not had a positive impact on economic growth. In contrast, investment in ports has shown a positive effect. Government investment in the road, port and irrigation sector began to have a positive impact on economic growth in the fourth year; however, the only asset in the road sector had a significant impact. Other studies supporting this finding are [19-20], which show that the infrastructure investment has a positive effect on economic growth. However, previous research did not specify the type of infrastructure and in what year investment began to show a positive impact.

The results of this study imply that in the medium and long term, investment in public infrastructure has a positive impact on economic growth. However, a general problem associated with this study is that this model assumes the co-efficiency of cross-sectional homogeneity. It may be that the fact coefficient can vary between regions due to differences in geographical, institutional, social and economic structures. Bloch et al. found the results of this regression only represent an average relationship, which does not apply to each country in the sample, [35].

To connect the production and distribution activities with the end consumers requires adequate road transportation. The availability of roads is expected to bridge the gap, although the relationship between the two is open for debate. In Indonesia, the infrastructure network development has encouraged the growth and development of new businesses such as small industrial businesses, transportation services, building materials and so on. In addition, road access promotes the spread of action carried out by the government and the community, so that the involvement of the village community increases. The next impact of the rise and expansion of business is imposed by an increase in the real income of the community.

Previous studies, supporting theresults of this study include [19]. Their results show the positive impact of investment in transportation and communication on economic growth. Boopen, in a study [36], analyzing the contribution of transportation investment to development in 38 Sub-Saharan African countries, concluded that transportation had been a contributor to the economic progress of these countries. Vlahinic Lenz et al. also proved that infrastructure plays an essential role in driving economic growth in Central and Eastern European Member States, [37]. In line with those findings, the results of [38] are the same for the case of East Asia.

The government, as a budget allocator hopes that the port infrastructure investment has economic benefits and impacts. Financial services cause impacts that can be measured directly in monetary terms. Meanwhile, the economic implications involve changes in infrastructure investment projects. After the benefits are measured, the effect can be observed. The results of this study indicate that government investment in the port infrastructure has a positive impact on economic growth, but not a significant one. The port infrastructure is one of the critical elements of the economy in Indonesia, which is an island nation. The insignificant impact of the port investment on growth is likely due to development of the port that has not been distributed evenly between provinces so that it has not been able to significantly cut the logistics costs.

Development of Indonesia's port cities on the coast continues to dominate. The towns that are still developing, urbanization is still high, minimum transportation costs for trade and land transportation infrastructure is still not right. Development of the port cities is increasingly shifting to the service sector, while the manufacturing industry is moving to hinterland cities or cities that do not have ports. 
Thus, cities without ports continue to grow due to manufacturing sector activity.

The findings in this study are in line with the research results of [39]. In their research in Tunisia, authors concluded that the public investment in the service sector port infrastructure was the recipient of the most significant benefits from the port sector investment. Another study also showed that the port investment in China and Korea had a considerable impact on economic growth, [40]. Although the port investment in China has a positive effect on economic growth, there are real differences at various regional levels.

The government investment in irrigation infrastructure has a positive impact on economic growth, but the effect is not significant. Previous studies for cases in Indonesia support the findings in this study. According to [41], an increase in the contribution of the agricultural sector to economic growth does not have a significant impact on people's income per capita. Data from the Central Statistics Agency show that in the 2011-2018 period, the harvested area of rice increased from 8.095 million hectares to 11.38 million hectares. Still, the reverse rice production decreased from 65.76 million tons to 59.2 million tons. Thus, land productivity has reduced from 8.12 tons per hectare to 5.2 tons per ha.

In contrast to the findings of [41], the results of [42] research show that the road infrastructure, irrigation and markets together have a positive effect on added value in the agricultural sector. Findings in this study contradict the results of research in [43], which found the coefficient of the farming sector to be negative and significant to economic growth.

The further research, related to the insignificant positive impact of irrigation investment on economic growth, shown in this study, is needed. Research can be focused on the location where the government builds irrigation because the accuracy of location selection will determine the magnitude of the impact on economic growth. The report [44] for Sri Lanka can be used as a reference. According to [44], in areas that have adequate access to irrigation infrastructure, poverty levels are low, while the highest poverty is found in the regions that do not have the irrigation infrastructure.

\section{Conclusions and recommendations}

The most crucial finding in this study is that the government investment in the road, port and irrigation infrastructure began to show a positive impact on economic growth in Indonesia in the fourth year. However, only investment expenditure for roads has a significant effect. Based on these findings, it is recommended that the government develop policies should focus on developing roads that connect remote areas and maintain sustainable and applicable roads that would ensure reasonable access and flow in Indonesia.

The role of the port is significant, considering that Indonesia is an island nation. The port infrastructure can increase the supply, as well as increase the foreign exchange reserves and reduce the overall commodity prices. The port investment has a positive but not significant impact on economic growth, which is likely due to the uneven development of the port infrastructure, especially on small islands that have abundant natural resource potential. For this reason, the government should follow up on results of research by increasing investment in ports to serve interregional areas. It is hoped that the port development will not only produce economic benefits but also create a balance between various economic sectors and between regions.

Finally, in the context of investment in irrigation infrastructure, the most important implication of findings in this study is that the government should focus on irrigation development in areas that are still isolated, since the accuracy of location in building infrastructure would determine the magnitude of impact on the economic growth.

\section{References}

[1] HOLTZ- EAKIN, D., SCHWARTZ, A. E. Infrastructure in a structural model of economic growth. Regional Science and Urban Economics [online]. 1995, 25(2), p. 131-151. ISSN 0166-0462. Available from: https://doi. org/10.1016/0166-0462(94)02080-Z

[2] CALDERON, C., SERVEN, L. Infrastructure and economic development in Sub-Saharan Africa. Journal of African Economies [online]. 2010, 19(1), p. 13-87. ISSN 0963-8024, eISSN 1464-3723. Available from: https://doi. org/10.1093/jae/ejp022

[3] STRAUB, S. Infrastructure and growth in developing countries: recent advances and research challenges. Policy Research Working Paper No. 4460. The World Bank Development Research Department Research Support Team, 2008.

[4] ASCHAUER, D. A. The role of public infrastructure capital in Mexican economic growth. Economia Mexicana. Nueva Epoca. 1998, VII(1), p. 47-78. ISSN 1665-2045. 
[5] ATIF, A., FLYVBJERG, B., BUDZIER, A., LUNN, D. Does infrastructure investment lead to economic growth or economic fragility? Evidence from China. Oxford Review of Economic Policy [online]. 2016, 32(3), p. 360-390. ISSN 0266-903X, eISSN 1460-2121. Available from: https://doi.org/10.1093/oxrep/grw022

[6] FOX, W. F. Strategic options for urban infrastructure management (English) [online]. Urban management programme policy paper; UMPP no. 17. Washington, D.C.: The World Bank, 1994. ISSN 1020-0215. Available from: http://documents.worldbank.org/curated/en/946371468765270932/Strategic-options-for-urbaninfrastructure-management

[7] GRIGG, N. DAN FONTANE, D. G. Infrastructure system management and optimization. In: Internasional Seminar Paradigm and Strategy of Infrastructure Management: proceedings. 2000.

[8] KODOATIE, R. J. Introduction to management: infrastructure / Pengantar manajemen: infrastruktur (in Indonesian). Yogyakarta: Pustaka Pelajar, 2005. ISBN 979-3237-9.

[9] CANNING, D., P. PEDRONI. The effect of infrastructure on long-run economic growth. Department of Economics Working Papers. Williamstown, MA: Williams College, Department of Economics, 2004.

[10] TODARO, M. P., SMITH, S. C. Economic development. 9. ed. England: Pearson Education Ltd., 2006. ISBN 9780321485731.

[11] ARROW, K., KURZ, M. Public investment, the rate of return and optimal fiscal policy. Baltimore, MD: The Johns Hopkins University Press, 1970. ISBN 978-1-61726-030-8.

[12] BARRO, R. J. Government spending in a simple model of exogenous growth. Journal of Political Economy [online]. 1990, 98, p. 103-125. ISSN 0022-3808, eISSN 1537-534X. Available from: https://doi.org/doi:10.1086/261726

[13] FUTAGAMI, K., MORITA, Y., SHIBATA, A. Dynamic analysis of an endogenous growth model with public capital. Scandinavian Journal of Economics [online]. 1993, 95, p. 607-625. ISSN 0347-0520, eISSN 1467-9442. Available from: https://doi.org/10.2307/3440914

[14] World Bank. World Development Report 1994: Infrastructure for development [online]. New York: Oxford University Press, 1994. Available from: https://openknowledge.worldbank.org/handle/10986/5977

[15] ISMAIL, N. W., MAHYIDEEN, J. M. The Impact of infrastructure on trade and economic growth in selected economies in Asia [online]. ADBI Working Paper Series No. 553. Tokyo, Japan: Asian Development Bank Institute, 2015. Available from: http://www.adb.org/publications/impact-infrastructuretrade-and-economicgrowth-selected-economies-asia/

[16] Global competitiveness index - World Economic Forum [online] [accessed 2020-01-16]. 2014. Available from: http://www.weforum.org/reports

[17] SHAH, A. Dynamics of public infrastructure, industrial productivity and profitability. Review of Economics and Statistics [online]. 1990, 74(1), p. 28-36. ISSN 0034-6535, eISSN 1530-9142. Available from: https://doi. org/10.2307/2109539

[18] UCHIMURA, K., GAO, H. The importance of infrastructure on economic development. Washington, DC: World Bank, Latin America and the Caribbean Regional Office, 1993.

[19] EASTERLY, W., REBELO, S. Fiscal policy and economic growth: an empirical investigation. Journal of Monetary Economics [online]. 1993, 32(3), p. 417-458. ISSN 0304-3932. Available from: https://doi.org/10.3386/w4499

[20] CANNING, D. A database of world stocks infrastructure, 1950-1995. World Bank Economic Review. 1998, 12(3), p. 529-547. ISSN 0258-6770, eISSN 1564-698X.

[21] ASCHAUER, D. A. Highway capacity and economic growth. Economic Perspectives. 1990, 14(5), p. 14-24. ISSN 0164-0682.

[22] NG, C. P, LAW, T. H., JAKARNI, F. M., KULANTHAYAN, S. Road infrastructure development and economic growth. IOP Conference Series: Materials Science and Engineering [online]. 2019, 512, 012045. ISSN 1757-8981, eISSN 1757-899X. Available from: https://doi.org/10.1088/1757-899X/512/1/012045

[23] DENG, P., LU, S., XIAO, H. Evaluation of the relevance measure between ports and regional economy using structural equation modelling. Transport Policy [online]. 2013, 27, p. 123-133. ISSN 0967-070X. Available from: https://doi.org/10.1016/j.tranpol.2013.01.008

[24] JUNG, B.-M. Economic contribution of ports to the local economies in Korea. The Asian Journal of Shipping and Logistics [online]. 2011, 27(1), p. 1-30. ISSN 2092-5212. Available from: https://doi.org/10.1016/S20925212(11)80001-5

[25] YOCHUM, G. R., AGARWAL, V. B. Economic impact of a port on a regional economy: note. Growth Change [online]. 1987, 18(3), p. 74-87. eISSN 1468-2257. Available from: https://doi.org/10.1111/j.1468-2257.1987.tb00082.x

[26] BOTTASSO, A, CONTI, M, FERRARI, C, MERK, O, TEI, A. The impact of port throughput on local employment: evidence from a panel of European regions. Transport Policy [online]. 2013, 27, p. 32-38. ISSN 0967-070X. Available from: https://doi.org/10.1016/j.tranpol.2012.12.001

[27] BOTTASSO, A, CONTI, M, FERRARI, C, TEI, A. Ports and regional development: a spatial analysis on a panel of European regions. Transportation Research Part A: Policy and Practice [online]. 2014. 65, p. 44-55. ISSN 0965-8564. Available from: https://doi.org/10.1016/j.tra.2014.04.006 
[28] HUSSAIN, I., HANJRA, M. A., TRIKAWALA, S., WIJERATNE, D. Impact of irrigation infrastructure development on dynamics of incomes and poverty econometric evidence using panel data from Sri Lanka. A collaborative research project initiated by the JBIC Institute, the Japan Bank for International Cooperation and undertaken by the International Water Management Institute (IWMI). 2003.

[29] ASCHAUER, D. A. Is public expenditure productive? Journal of Monetary Economics [online]. 1989, 23(2), p. 177-200. ISSN 0304-3932. Available from: https://doi.org/10.1016/0304-3932(89)90047-0

[30] MUNNELL, A. Why has productivity growth declined? Productivity and public investment. New England Economic Review. 1990, Jan, p. 3-22. ISSN 0028-4726.

[31] KAMPS, CH. The dynamic effects of public capital: VAR evidence for 22 OECD countries [online]. Kiel Working Paper, No. 1224. Kiel: Kiel Institute for World, 2004. Available from: http://hdl.handle.net/10419/17768

[32] FEDDERKE, J. W., PERKINS, P., LUIZ, J. M. Infrastructural investment in long-run economic growth: South Africa 1875-2001. World Development [online]. 2006, 34(6), p. 1037-1059. ISSN 0305-750X. Available from: https://doi.org/10.1016/j.worlddev.2005.11.004

[33] SAHOO, P., DASH, R. K. Infrastructure development and economic growth in India. Journal of the Asia Pacific Economy [online]. 2009, 14(4), p. 351-365. ISSN 1354-7860, eISSN 1469-9648. Available from: https://doi. org/10.1080/13547860903169340

[34] SAHOO, P., DASH, R. K., NATARAJ, G. China's growth story: the role of physical and social infrastructure. Journal of Economic Development [online]. 2012, 37(1), p. 53-75. ISSN 0254-8372. Available from: https://doi. org/10.35866/caujed.2012.37.1.003

[35] BLOCH, H, TANG, S. H. K. The role of financial development in economic growth. Progress in Development Studies [online]. 2003, 3(3), p. 243-251. ISSN 1464-9934, eISSN 1477-027X. Available from: https://doi. org/10.1191/1464993403ps063pr

[36] BOOPEN, S. Transport infrastructure and economic growth: evidence from Africa using dynamic panel estimates. The Empirical Economics Letters. 2006, 5(1), p. 37-52. ISSN 16818997.

[37] VLAHINIC LENZ, N., PAVLIC SKENDER, H., MIRKOVIC, P. A. The macroeconomic effects of transport infrastructure on economic growth: the case of Central and Eastern E.U. member states. Economic ResearchEkonomska Istrazivanja [online]. 2019, 31(2018-1), p. 1953-1964. ISSN 1331-677X, eISSN 1848-9664. Available from: https://doi.org/10.1080/1331677X.2018.1523740

[38] SEETHAPALLI, K, BRAMATI, M. C., VERDES, D. How relevant is the infrastructure to growth in east Asia? [online]. World Bank Policy Research Working, Paper No. 4597. 2008. Available from: https://doi.org/10.1596/18139450-4597

[39] JOULE, T. A., ALLOUCHE, M. A. Impacts of seaport investment on economic growth. Promet - Traffic and Transportation [online]. 2016, 28(4), p. 365-370. ISSN 0353-5320, eISSN 1848-4069. Available from: https://doi. org/10.7307/ptt.v28i4.1933

[40] JIANG, N. Seaport investment and economic development in China. Dalian, China: Dalian Marine University Press, 2010.

[41] MARYANINGSIH, N., HERMANSYAH, O., SAVITRI, M. The impact of infrastructure to Indonesian economy / Pengaruh infrastruktur terhadap pertumbuhan ekonomi Indonesia (in Indonesian). Buletin Ekonomi Moneter dan Perbankan [online]. 2014, 17(1), p. 62-98. ISSN 1410-8046, eISSN 2460-9196. Available from: https://doi. org/10.21098/bemp.v17i1.44

[42] ELWA P, F., TAN, S., ACHMAD, E. The impact of infrastructure development to agriculture sector in Muaro Jambi / Pengaruh pembangunan infrastruktur terhadap pengembangan sektor pertanian di kabupaten Muaro Jambi (in Indonesian). Jurnal Perspektif Pembiayaan dan Pembangunan Daerah [online]. 2013, 1(1), p. 29-34. ISSN 2338-4603, eISSN 2355-8520. Available from: https://doi.org/10.22437/ppd.v1i1.1339

[43] DEMURGER, S., Infrastructure development and economic growth: an explanation for regional disparities in China? Journal of Comparative Economics [online]. 2001, 29(1), p. 95-117. ISSN 0147-5967. Available from: https://doi.org/10.1006/jcec.2000.1693

[44] HUSSAIN, I., HANJARA, M., THRIKWALA, S., WIJERATHNA, D., SHINKAI, N., SAWADA, Y. Impact of irrigation infrastructure development on dynamics of incomes and poverty: econometric evidence using panel data from Sri Lanka. JBICI Research Paper No. 32. Japan: JBIC, 2007. 